\title{
Biokonversi Pelepah Daun Nipah Menggunakan Jamur Tiram Putih Ditinjau Dari Komposisi Kimia dan Kecernaan Serat
}

\author{
Suryadi, Hardi Syafria \\ Dosen Fakultas Peternakan Universitas Jambi
}

\begin{abstract}
The study aims to determine the chemical composition and digestibility of midrib palm leaves from bioconversion results. Solid bioconversion using white oyster mushroom inoculum as a starter. This study used a completely randomized design (RAL) with 6 treatments and 3 replications. As a treatment the white oyster mushroom inoculum consisted of 6 levels, namely 0g (with inoculum), $5 \mathrm{~g}, 10 \mathrm{~g}, 15 \mathrm{~g}, 20 \mathrm{~g}$ and $25 \mathrm{~g} \mathrm{~kg}^{-1}$ substrate. The variables measured are the chemical composition and digestibility of nipah leaf midrib fiber bioconversion products. The results showed that organic matter content, ADF digestibility and nipah leaf midrib cellulosa bioconversion results were significantly different $(P<0.05)$ but the dry matter content, crude protein and NDF digestibility did not show significant differences $(P>0.05)$ due to the levels of white oyster mushroom inoculum. The best digestibility occurred at the levels of white oyster mushroom inoculum $20 \mathrm{~g} \mathrm{kg-1}$ substrate with acid digestibility fiber $27,31 \%$ and cellulose $31,08 \%$. It can be concluded thah the level of white oyster mushroom inoculum $20 \mathrm{~g} \mathrm{kg-1} \mathrm{substrate} \mathrm{for} \mathrm{nipah} \mathrm{leaf} \mathrm{midrib}$ bioconversion results is the best.
\end{abstract}

Keyword: bioconversion; nipah leaf midrib; white oyster mushroom; chemical composition; fiber digestibility

\section{PENDAHULUAN}

Salah satu hasil ikutan tanaman mangrove adalah pelepah daun nipah, yang jumlahnya dapat mencapai 40 juta per hektar/tahun (Baharudin dan Taskirawati, 2011). Pelepah nipah merupakan sisa pengambilan daun nipah sebagai bahan pembuat atap yang belum termanfaatkan oleh petani dan sangat potensial sebagai bahan pakan ternak, namun karena kualitas nutrisi yang rendah,

Kualitas pelepah daun nipah sebagai pakan dapat ditingkatkan melalui aplikasi bioteknologi, dalam penelitian ini adalah biokonversi dengan menggunakan jamur tiram putih (Pleurotus ostreatus). Aplikasi teknologi biokonversi ini lebih menguntungkan karena selain dapat meningkatkan nilai nutrisi, juga tidak berbahaya, tidak menimbulkan polusi dan biaya relatif murah. Jamur tiram putih sebagai jamur penghasil enzim fenol oksidase (laktase, peroksidase, dan tirosinase) mampu mendegradasi lignoselulosa dan lignohemiselulosa (Ghunu dan Tarmizi, 2006). Proses biokonversi dapat menurunkan kadar fraksi serat atau karbohidrat struktural, meningkatkan kadar protein (miselium jamur sebagai sumber nitrogen), selulosa dan hemiselulosa yang didegradasi menjadi tersedia. Pengolahan pelepah daun nipah melalui proses biokonversi akan menghasilkan pakan yang berkualitas baik.

Inokulum jamur tiram putih sebagai starter diinokulasikan dalam substrat biokonversi saat kultur mikroba pada fase pertumbuhan eksponensial. Dosis inokulum jamur tiram putih pada biokonversi substrat padat sangat bervariasi dari $0,5-20 \%$ dari total berat bahan fermentasi (Wijono et al., 1988). Hal ini sangat erat kaitannya dengan aktivitas enzim yang dihasilkan jamur. Penggunaan jamur tiram putih di dalam proses biokonversi rumput Kume kering dapat meningkatkan kandungan protein kasar dan menurunkan bahan kering, bahan organik dan serat kasar (Ghunu dan Tarmizi, 2006). Hasil penelitian Ghunu (1998) pada ampas tebu menggunakan inokulum jamur tiram putih menghasilkan kecernaan ADF 42,12\% NDF 47,29\%, hemiselulosa $52,99 \%$, selulosa $44,39 \%$ dan lignin $12,02 \%$.
Pada penelitian ini dipelajari proses biokonversi pelepah daun nipah menggunakan jamur tiram putih ditinjau dari komposisi kimia dan kecernaan komponen serat.

\section{METODE PENELITIAN}

Bahan yang digunakan dalam penelitian adalah pelepah nipah, Inokulum jamur tiram putih, kapur $\mathrm{CaCO}_{3}$, cairan rumen, larutan/bahan kimia dan perlengkapan untuk in vitro.

Alat yang digunakan adalah timbangan pakan dan peralatan laboratorium (antara lain: timbangan analitik, oven, aqua shake, kain kasa, tabung fermentor, centrifuge, kertas saring, pompa vakum, termos air, thermometer, dII).

Pelepah daun nipah yang diperoleh di sekitar Muara Sabak di chopper ukuran $\pm 2-4 \mathrm{~cm}$, lalu dikeringkan dan digiling. Inokulum jamur tiram putih (Pleurotus ostreatus), diperoleh dari petani jamur (Edi Jamur) Jl. Swadaya raya No. 5 Rt. 07 Bagan Pete Kota Jambi. Bahan aditif terdiri atas dedak halus (sebagai sumber karbon dan nitrogen); $\mathrm{CaCO}_{3}$ (sebagai sumber kalsium dan pengatur $\mathrm{pH}$ substrat agar tetap berkisar 5,1-7,0). Air digunakan untuk membasahi substrat sehingga tercipta kondisi kadar air substrat yang diperlukan untuk pertumbuhan media jamur dan sebagai bahan pelarut zat-zat makanan. Cairan rumen berasal dari sapi bali berfistula rumen berumur \pm 3 tahun

\section{Pelaksanaan Biokonversi}

Sebagai media tumbuh jamur disiapkan $65 \%$ pelepah daun nipah, $33 \%$ dedak padi dan $2 \% \mathrm{CaCo}_{3}$ (kapur) dicampur secara merata, lalu ditambahkan air $70 \%$ dan dilakukan pengomposan selama 2 hari. Substrat dimasukkan ke dalam kantong polipropilen masing-masing sebanyak $1 \mathrm{~kg}$ dan dipadatkan, mulut kantong plastik ditutup dengan menggunakan cincin paralon dan dilipat keluar dan diikat dengan karet gelang dan ditutup kapas. Substrat disterilisasi dalam drum pengukus selama 8 jam, lalu didinginkan selama 24 jam. Selanjutnya substrat diinokulasi dengan level inokulum jamur tiram putih $0 \mathrm{~g}$ (tanpa inokulum) $5 \mathrm{~g}, 10 \mathrm{~g}, 15 \mathrm{~g}, 20 \mathrm{~g}$ 
dan, $25 \mathrm{~g} \mathrm{~kg}^{-1}$ substrat dan diinkubasi dalam ruang inkubasi dengan lama inkubasi 35 hari sampai baglog berwarna putih. Suhu ruang inkubasi harus dijaga dalam kondisi yang stabil dan rendah cahaya yaitu 22$28^{\circ} \mathrm{C}$ dengan kelembaban $70-90^{\circ} \mathrm{C}$.

Substrat hasil biokonversi (PDNHB) kemudian dikeluarkan dari baglog dan diambil sampel masingmasing baglog $200 \mathrm{~g}$ dan dikeringkan dalam oven selama 48 jam pada suhu $60^{\circ} \mathrm{C}$ dan 24 pada suhu $105^{\circ} \mathrm{C}$. Kemudian sampel digiling halus selanjutkan dilakukan analisis komposisi kimia yaitu bahan kering, bahan organik, dan protein kasar dan kecernaan serat secara in vitro.

Penelitian dilakukan menggunakan Rancangan Acak Lengkap (RAL) dengan perlakuan 6 level inokulum jamur tiram putih dan ulangan 3 tiap perlakuan. Data dianalisis dengan analisis ragam (ANOVA) dan bila terdapat perbedaan maka dilanjutkan dengan uji jarak Duncan (Steel and Torrie., 1995)

Peubah yang diamati adalah komposisi kimiawi dan kecernaan serat (KCNDF), kecernaan serat
(KCADF) dan kecernaan selulosa produk biokonversi. Nilai kecernaan KCNDF, KCADF dan KC selulosa ditetapkan dengan menggunakan metode Tilley and Terry yang dimodifikasi oleh Sutardi (1980). Kadar NDF dan ADF dianalisis, masing-masing dengan mengekstraksi contoh dengan larutan detergen netral dan larutan detergen asam (AOAC, 2000). Bahan organik adalah bahan yang hilang setelah pembakaran pada suhu $600^{\circ} \mathrm{C}$. Kadar protein diukur secara destruksi dengan asam sulfat dan kyeldahl dilanjutkan dengan pegukuran $\mathrm{N}$ menggunakan auto analyzer (AOAC, 2000).

\section{HASIL DAN PEMBAHASAN Komposisi kimia produk biokonversi}

Rataan kandungan bahan kering, bahan organik, dan protein kasar pelepah daun nipah hasil biokonversi pada level inokulum jamur tiram putih yang berbeda dapat dilihat pada Tabel 1.

Tabel 1. Rataan komposisi kimia pelepah daun nipah hasil biokonersi

\begin{tabular}{cccc}
\hline Level inokulum jamur tiram putih & & \multicolumn{2}{c}{ Komposisi kimia (\%) bahan kering } \\
& Bahan kering & Bahan organik & Protein kasar \\
\hline $0 \mathrm{~g}$ & $41,62 \pm 4,38$ & $34,62 \pm 2,71 \mathrm{a}$ & $3,79 \pm 0,71$ \\
$5 \mathrm{~g}$ & $36,96 \pm 1,78$ & $25,63 \pm 0,46 \mathrm{c}$ & $4,35 \pm 0,75$ \\
$10 \mathrm{~g}$ & $35,43 \pm 1,85$ & $29,77 \pm 2,65 \mathrm{~b}$ & $4,37 \pm 0,58$ \\
$15 \mathrm{~g}$ & $37,26 \pm 1,24$ & $26,60 \pm 0,80 \mathrm{bc}$ & $4,61 \pm 0,43$ \\
$20 \mathrm{~g}$ & $36,55 \pm 0,45$ & $28,33 \pm 1.12 \mathrm{bc}$ & $4,91 \pm 0,70$ \\
$25 \mathrm{~g}$ & $36,04 \pm 1,76$ & $25,70 \pm 1,72 \mathrm{c}$ & $4,25 \pm 0,96$
\end{tabular}

Keterangan: Superskrip yang berbeda pada kolom yang sama menunjukkan perbedaan nyata sekurang-kurangnya $(P<0,05)$.

\section{Kandungan bahan kering}

Hasil analisis ragam menunjukkan bahwa level inokulum jamur tiram putih tidak berpengaruh nyata $(P>0,05)$ terhadap kandungan bahan kering pelepah nipah hasil biokonversi, namun ada kecenderungan berbeda nyata (Tabel 1). Hal ini diduga karena miselium yang tumbuh belum maksimal sehingga belum banyak komponen-komponen lainnya dari substrat yang dirombak oleh enzim fenol oksidase menjadi energi untuk pertumbuhan jamur. Menurut Kasmiran (2011) semakin banyak mikroorganisme yang tumbuh maka semakin banyak pula zat makanan yang dirombak menjadi energi, akibatnya molekul air yang dihasilkan dari proses metabolisme juga meningkat. Sebagian besar molekul air akan tinggal dalam produk dan sebagian lagi akan keluar dari produk (Fardiaz, 1988). Molekulair yang tinggal dalam produk akan meningkatkan kadar air dalam produk dan menurunkan kandungan bahan kering produk (Winarno et al., 1986).

Selain itu mungkin disebabkan waktu fermentasi yang kurang optimal sehingga pertumbuhan miselium belum optimal pada saat proses fermentasi sehingga kandungan bahan kering pelepah daun nipah hasil biokonversi tidak berbeda diantara semua perlakuan. Hal ini sejalan dengan hasil penelitian Hadar et al (1993) bahwa fermentasi jerami gandum menggunakan Pleurotus osteoratus sampai 30 hari memberikan pengaruh yang tidak nyata terhadap kandungan bahan kering jerami gandum.

\section{Kandungan bahan organik}

Level inokulum berpengaruh nyata $(P<0,05)$ terhadap kandungan bahan organik pelepah daun nipah hasil biokonversi, yang pada awalnya (sebelum biokonversi) adalah $34,62 \pm 2,71 \%$ dan setelah biokonversi menjadi $25,63 \pm 0,46 \%$. Level inokulum $10 \mathrm{~g}$ $\mathrm{kg}^{-1}$ substrat tidak berberbeda nyata $(P>0,05)$ dengan level inokulum $15 \mathrm{~g}$ dan $20 \mathrm{~g} \mathrm{~kg}^{-1}$ substrat. Penurunan kandungan bahan organik penelitian ini disebabkan terjadinya degradasi terhadap komponen-komponen lainnya di dalam substrat sejak awal inkubasi hingga waktu tertentu (35 hari) oleh aktivitas enzim fenol oksidase yang diproduksi jamur tiram putih.

Penurunan bahan organik selama proses biokonversi ini didukung oleh hasil penelitian Hadar et al (1993), dimana terjadi penurunan nutrisi terutama bahan organik pada jerami gandum yang difermentasi oleh Pleurotus osteoratus dan penurunan bahan organik tertinggi sebesar $20 \%$ dalam waktu fermentasi 30 hari. Perbedaan ini disebabkan oleh perbedaan bahan yang digunakan, keadaan fisik bahan dan waktu inkubasi.

\section{Kandungan Protein Kasar}

Level inokulum tidak berpengaruh nyata $(P>0,05)$ terhadap kandungan protein kasar pelepah daun nipah hasil biokonversi, dimana kandungan protein kasar terendah diperoleh pada perlakuan $0 \% \mathrm{~kg}^{-1}$ (tanpa inokulum), sedangkan yang tertinggi pada level inokulum 
$20 \mathrm{~g} \mathrm{~kg}^{-1}$ substrat (Tabel 1). Perubahan kandungan protein kasar selama proses biokonversi tidak nyata. Hal ini disebabkan oleh karena miselium yang tumbuh pada baglog masih menipis, belum merata sehingga pertumbuan miselium belum maksimal pada setiap perlakuan akibatnya berpengaruh terhadap kandungan protein kasar substrat, walaupun terjadi peningkatan protein. Pembentukan protein mencapai puncaknya pada saat pembentukan miselium selesai (Santosa, 1996). Semakin tinggi level inokulum jamur tiram menyebabkan lebih banyaknya miselium terbentuk, disertai dengan meningkatnya nitrogen total secara proporsional karena terdegradasinya komponen serat
(Nicolini et al., 1987), sebaliknya bahan organik menurun.

Peningkatan level jamur tiram putih berpengaruh positif terhadap kepadatan populasi jamur tiram putih, pada gilirannya juga terhadap produksi enzim untuk menguraikan substrat menjadi pembentuk-pembentuk protein (Zadrazil dan Kurtzman Jr., 1984).

\section{Kecernaan komponen serat hasil biokonversi}

Hasil pengukuran nilai kecernaan komponen serat secara in vitro dan hasil analisis statistik dapat dilihat pada gambar 2 .

Tabel 2. Rataan nilai kecernaan serat pelepah daun nipah hasil biokonversi

\begin{tabular}{cccc}
\hline Level inokulum jamur tiram putih & NDF & Kecernaan Serat $(\%)$ bahan kering \\
& ADF & Selulosa \\
\hline $0 \mathrm{~g}$ & $14,60 \pm 1,20$ & $12,37 \pm 4,13 \mathrm{a}$ & $16,80 \pm 5,86 \mathrm{a}$ \\
$5 \mathrm{~g}$ & $18,12 \pm 2,42$ & $14,43 \pm 4,27 \mathrm{~b}$ & $14,43 \pm 6,58 \mathrm{~b}$ \\
$10 \mathrm{~g}$ & $22,99 \pm 1,26$ & $21,77 \pm 0,78 \mathrm{c}$ & $23,37 \pm 3,02 \mathrm{~b}$ \\
$15 \mathrm{~g}$ & $16,81 \pm 2,96$ & $18,63 \pm 2,10 \mathrm{c}$ & $23,13 \pm 4,09 \mathrm{~b}$ \\
$20 \mathrm{~g}$ & $22,45 \pm 3,64$ & $27,31 \pm 3,25 \mathrm{~d}$ & $31,08 \pm 2,27 \mathrm{c}$ \\
$25 \mathrm{~g}$ & $24,55 \pm 3,19$ & $18,76 \pm 3,64 \mathrm{~d}$ & $23,56 \pm 4,89 \mathrm{~cd}$ \\
\hline
\end{tabular}

Keterangan: Superskrip yang berbeda pada kolom yang sama menunjukkan perbedaan nyata sekurang-kurangnya $(P<0,05)$.

\section{Kecernaan Neutral Detergent Fiber (NDF)}

Neutral Detergent Fiber merupakan zat makanan yang tidak larut dalam detergent neutral dan merupakan bagian terbesar dari dinding sel tanaman. Bahan ini terdiri atas hemiselulosa, selulosa, lignin, silika dan beberapa protein fibrosa (Van Soest, 1994).

Hasil analisis sidik ragam pada inkubasi 48 jam menunjukkan bahwa level inokulum selama proses fermentasi tidak nyata $(P>0,05)$ mempengaruhi kecernaan NDF pelepah daun nipah hasil biokonversi. Hal ini disebabkan karena kandungan serat kasar tidak berbeda nyata $(P>0,05)$ dari masing-masing perlakuan sehingga berpengaruh terhadap kecernaan NDF (Tabel 2).

Selain itu mungkin disebabkan enzim fenol oksidase yang dihasilkan jamur tiram putih belum mampu merenggangkan atau melonggarkan ikatan lignoselulosa dan lignohemiselulosa dari substrat tersebut akibatnya kecernaan NDF pelepah daun nipah hasil biokonversi tidak berbeda atau relatif sama.

Van Soest (1982) menyatakan bahwa kecernaan serat detergent (NDF) tergantung dari lignifikasi fraksi tersebut, selulosa dan hemiselulosa yang terikat lignin tidak dapat dicerna oleh miroba rumen sehingga akan menurunkan kecernaan bahan pakan. Tillman et al. (1991) menyatakan bahwa kandungan serat kasar mempunyai pengaruh terbesar terdapat kecernaan.

\section{Kecernaan Acid Detergent Fiber (ADF)}

Acid Detergent Fiber merupakan zat makanan yang tidak larut dalam detergen asam. Acid detergent fiber terdiri atas selulosa, lignin dan silika (Van Soest., 1994)

Level inokulum berpengaruh sangat nyata $(P<0,01)$ terhadap nilai kecernaan ADF pelepah daun nipah hasil biokonversi (Tabel 2). Level inokulum $5 \mathrm{~g} \mathrm{~kg}^{-1}$ substrat berbeda nyata $(P<0,05)$ dengan level inokulum
$10 \mathrm{~g}, 15 \mathrm{~g}, 20 \mathrm{~g}, 25 \mathrm{~g}$ dan $0 \mathrm{~g} \mathrm{~kg}-1$ substrat (tanpa inokulum) terhadap nilai kecernaan ADF pelepah daun nipah produk biokonversi. Level inokulum $25 \mathrm{~g} \mathrm{kg-1}$ substrat tidak berbeda nyata $(P>0,05)$ dengan level inokulum $15 \mathrm{~g} \mathrm{~kg}^{-1}$ substrat. Demikian pula antara level inokulum $5 \mathrm{~g} \mathrm{~kg}^{-1}$ substrat dengan level $0 \mathrm{~g} \mathrm{~kg}^{-1}$ substrat (tanpa inokulum) tidak berbeda nyata $(P>0,05)$. Pada level inokulum $20 \mathrm{~g} \mathrm{~kg}^{-1}$ substrat diperoleh nilai kecernaan ADF yang lebih tinggi dibandingkan dengan perlakuan lainnya.

Peningakatan nilai kecernaan ADF ini diakibatkan oleh adanya aktivitas enzim fenol oksidase yang diproduksi oleh jamur tiram putih yang berperan menkomposisi lignoselulosa sehingga nilai nutrisi dan kecernaan meningkat.

Nilai kecernaan ADF sebelum biokonversi adalah $12,37 \pm 4,13 \%$ dan setelah biokonversi menjadi $27,31 \pm 3,25 \%$ maka terjadi peningkatan kecernaan ADF sebesar 14,94\%. Peningkatan nilai kecernaan ADF penelitian ini lebih rendah dibandingkan hasil penelitian Ghunu (1998) dimana nilai kecernaan ADF ampas tebu sebesar 42,12\%. Perbedaan nilai kecernaan tersebut disebabkan oleh perbedaan bahn dan komposisinya, metode yang digunakan dan lama inkubasi.

\section{Kecernaan Selulosa}

Selulosa merupakan komponen utama penyusun dinding sel tanaman, berikatan dengan lignin dan membentuk lignoselulosa.

Hasil analisis statistik pada inkubasi 48 jam menunjukkan bahwa level inokulum berpengaruh nyata $(\mathrm{P}<0,05)$ terhadap kecernaan selulosa pelepah daun nipah produk biokonversi (Tabel 2).

Level inokulum $20 \mathrm{~g} \mathrm{~kg}^{-1}$ substrat nyata $(P<0,05)$ lebih tinggi dibandingkan level inokulum $25 \mathrm{~g}, 15 \mathrm{~g}, 10 \mathrm{~g}$, $5 \mathrm{~g}$ dan $0 \mathrm{~g} \mathrm{~kg}^{-1}$ substrat (tanpa inokulum) terhadap kecernaan selulosa pelepah daun nipah hasil 
biokonversi. Level inokulum $25 \mathrm{~g} \mathrm{~kg}-1$ substrat tidak berbeda nyata $(P>0,05)$ dibandingkan level inokulum $15 \mathrm{~g}$ dan $10 \mathrm{~g} \mathrm{~kg}^{-1}$ substrat dan antara level inokulum $5 \mathrm{~g}$ $\mathrm{kg}^{-1}$ substrat dengan level $0 \mathrm{~g} \mathrm{~kg}^{-1}$ substrat (tanpa inokulum) juga tidak berbeda nyata $(P>0,05)$.

Peningkatan kecernaan selulosa ini diakibatkan oleh adanya aktivitas enzim fenol oksidase dari jamur tiram putih yang berperan aktif mendegradasi lignoselulosa sehingga kandungan lignin dan silika menjadi rendah dan kecernaan selulosa meningkat. Sesuai dengan pendapat Sullivan (1965) bahwa kandungan lignin berkorelasi negatif dengan degradasi selulosa

Kecernaan selulosa sebelum biokonversi yaitu $14,43 \%$ dan setelah biokonversi menjadi 31,08\%, maka terjadi peningkatan sebesar $16,65 \%$. Nilai kecernaan pada penelitian ini lebih rendah dibandung ini tertinggi diperoleh pada level inokulum $20 \mathrm{~g} \mathrm{~kg}^{-1}$ substrat yaitu $31,08 \%$ sedangkan terendah pada level inokulum $5 \mathrm{~g} \mathrm{kg-}$ 1 substrat yaitu 14,437\%. Nilai kecernaan selulosa ini lebih rendah dibandingkan dengan hasil penelitian Ghunu (1998) dimana kecernaan selulosa ampas tebu yaitu sebesar 44,39 \%. Perbedaan nilai kecernaan tersebut disebabkan oleh karena perbedaan komposisi bahan dan metode yang digunakan serta lama inkubasi

Nilai kecernaan selulosa pelepah daun nipah produk biokonversi pada level inokulum $25 \mathrm{~g} \mathrm{~kg}-1$ substrat berbeda tidak nyata $(P>0,05)$ dibandingkan dengan level inokulum $15 \mathrm{~g}$ dan $10 \mathrm{~g} \mathrm{~kg}^{-1}$ substrat dan antar level inokulum $5 \mathrm{~g} \mathrm{~kg}^{-1}$ dengan level $0 \mathrm{~g} \mathrm{~kg} \mathrm{-1}$ substrat juga tidak berbeda, hal ini karena kandungan lignin pelepah daun nipah produk biokonversi masingmasing perlakuan relatif sama. Smith et al. (1970) menyatakan bahwa lignin yang terkandungan dalam suatu bahan akan menurunkan tinggkat degradasi dinding sel bahan tersebut. Kandungan lignin yang relatif sama akan menyebabkan kecernaan yang relatif sama pula.

\section{SIMPULAN}

Kandungan bahan organik, kecernaan ADF dan selulosa pelepah daun nipah hasil biokonversi berbeda nyata $(P<0,05)$ tetapi kandungan bahan kering, protein kasar dan kecernaan NDF tidak menunjukkan perbedaan yang nyata $(P<0.05)$ akibat level inokulum jamur tiram putih. Kecernaan terbaik terjadi pada level inokulum $20 \mathrm{~g} \mathrm{~kg}^{-1}$ substrat dengan kecernaan Acid Detergent Fiber (ADF) 27,31\% dan selulosa 31,08\%.

\section{DAFTAR PUSTAKA}

AOAC. 2000. Official Methods of Analysis. 12th Edition. Benjamin Franklin, Washington, D.C.

Baharuddin dan I. Taskirawati. 2011. Buku Ajar. Hasil Hutan Bukan Kayu. Fakultas Kehutanan. Universitas Hasanuddin.Makasar.

Ghunu, S. 1998. Efek Dosis Inokulum dan Lama Bioconversi Ampas Tebu Sebagai Bahan Pakan oleh Jamur Tiram Putih (Pleurotus Ostreatus) Tehadap Kandungan Komponen Serat, Protein Kasar dan Energi Dapat Dicerna pada Domba . Tesis. Program Pascasarjana, Universitas Padjadjaran, Bandung
Ghunu, S dan Tarmizi, A.R. 2006. Perubahan Komponen Serat Rumput Kume (Sorghum Plumosum Var. Timorense) Hasil biokonversi Jamur Tiram Putih (Pleurotus ostreatus) Akibat kadar Air Substrat dan Dosis Inokulum yang Berbeda. Jurnal IImu Ternak. Volume 6 No. 2. Hal: $81-86$.

Hadar, Y., Z. Kerem and B. Gorodecki. 1993. Biodegradation of Lignocellulose Agricultural Wastes by Pleuratus ostreatus. Jurnal of Biotechnology. 30: 133-139

Nicolini, I., C. Von Hunolstein, and A. Carilli. 1987. Solid State Fermentation of Orange Peel dan Grape Stalks by Pleurotus ostreatus, Agrocybeaegerita and Armillariella mellea. Appl. Microbiology Biotechnology. 26: 95-98

Santosa, U. 1996. Efek Jerami Padi yang Difermentasi oleh Jamur Tiram Putih (Pleurotus ostreatus) Terhadap Penggemukan Sapi JantanPeranakan Onggle. Disertasi. Program Pascasarjana, Universitas Padjadjaran, Bandung.

Smith, L.W., H.K. Goering., D.R. Woldo and C.H. Gordon. 1970. In vitro Digestion Rate of Forage Cell wall Component.Anim. Sci. Reaseach Division, USDA, Betsville, Maryland.

Steel, R.G.D. dan J.H. Torrie. 1995. Prinsip dan Prosedur Statistika. Suatu pendekatan biometrika. Alih bahasa, Bambang Sumantri. Ed. 2. PT. Gramedia Pustaka Utama, Jakarta.

Sullivan, J.T. 1965. Studies of the hemicelluloses of forage plants. Chemist, Crops Research Division Agricultural Research Service. USDA. University Park. Pa. 16802.

Sutardi, T. 1980. Landasan IImu Nutrisi. Jilid I. Departemen IImu Makanan Ternak, Fakultas Peternakan IPB, Bogor.

Tillman, A.P., H. Hartadi., S. Reksohadiprodjo., P. Suharto dan S. Lebdosoekojo. 1991. IImu MakananTernak Dasar. Gadjah Mada University Press, Yogyakarta.

Van Soest, P.J. 1994. Nutrition Ecology of Ruminant: Ruminant Metabolisme, Nutrition strategis Decalullotic Fermentation and the Chemestry of Forage and Plant Fibers. Cornell Univ. O and B. Books, Inc. New York.

Wijono, D.B., B. Sarjono., Haryono dan D. Wibowo. 1988. Prinsip-prinsip Teknologi Fermentasi. Pusat Antar Universitas (PAU) Pangan dan Gizi, Universitas Gajah Mada, Yogyakarta.

Zadrazil, F., and R. H. Kurtzam Jr. 1984. The Biology of Pleurotus Cultivation in The Tropics. In: Chang. S. T., and T.H. Quimio (Editors). Tropica Mushrooms, Biological Nature and Cultivation Methods. The Chinese University Press, Hongkong. P.277-296. 